\title{
SOCIAL MEDIA ADDICTION, CRITICAL THINKING AND ACHIEVEMENT EMOTIONS AMONG EFL STUDENTS IN THAILAND
}

\author{
Darrin Thomas \\ Faculty of Education, Asia-Pacific International University, 195, Muak Lek, \\ Muak Lek District, Saraburi 18180, Thailand \\ E-mail: dtsac18803@gmail.com
}

Publication date: 30 June 2020

To cite this article: Thomas, D. (2020). Social media addiction, critical thinking and achievement emotions among EFL students in Thailand. Asia Pacific Journal of Educators and Education, 35(1),157-171. https://doi.org/10.21315/apjee2020.35.1.9

To link to this article: https://doi.org/10.21315/apjee2020.35.1.9

\begin{abstract}
Social media use has grown tremendously and has led to research in terms of its addictive power. The purpose of this study was to explore the link among social media addiction, critical thinking, and achievement emotions. Using path analysis, a sample was drawn from 229 university students. The results indicated that social media addiction has a strong negative relationship with achievement emotions and a weak negative relationship with critical thinking. Critical thinking has a weak positive relationship with achievement emotions. The final model with critical thinking and social media addiction explains $27 \%$ of the variance of achievement emotions. This indicates that students should exercise care with their social media use as individuals who agree with statements indicating addiction also agree with statements related to having negative emotions towards achievement in an academic context.
\end{abstract}

Keywords: Social media addiction, achievement emotions, Thailand, critical thinking

\section{INTRODUCTION}

Social media use continues to grow at unprecedented rates with over two billion users worldwide representing $28 \%$ of the entire population (Statista, 2018). College students spend approximately two hours a day using social media and half of the users state that it would be difficult to give up social media (Smith \& Anderson, 2018; Go-Global, 2014). The results of such continuous use of social media has led to such psychological strain as guilt, depression, isolation, and even 
such physical maladies as headaches, carpal tunnel syndrome, and blurred vision (PsychGuides, 2018). Several studies have found that the emotional state of a student can affect their academic performance (Goetz et al., 2012; Pekrun, Goetz, Daniels, Stupinsky, \& Perry, 2010; Pekrun, Hall, Goetz, \& Perry, 2014). Therefore, it is critical to explore the potential if there is a link between social media addiction and the emotions students portray when placed in an academic environment such as the classroom. However, the literature has focused extensively on looking at academic performance (Lau, 2017; Lepp, Barkley, \& Karpinkski, 2015; Samaha $\&$ Hawi, 2016). Furthermore, there is a large body of research that examines social media addiction but not as strong of a body of literature that looks at social media addiction's relationship with critical thinking and achievement emotions.

There are pressing demands for students to acquire critical thinking skills during their tertiary studies (Freedberg, 2016). Currently, the success of teaching critical thinking in college is mixed with conflicting reports (Belkin, 2017; Lane \& Oswald, 2016). Few studies have considered the interplay of social media addiction, critical thinking, and the emotions students experience when achieving academic goals (Ranellucci, Geotz, \& Hall, 2015). In addition, Thailand is one of the top users of social media in the world while also struggling with the development of critical thinking at the tertiary level (Fernquest, 2017; Leesa-Nguansak, 2018). This indicates that social media addiction may be a problem in the context of Thailand due to the high usage rate of social media in combination with developing critical thinking skills.

Therefore, the purpose of this study is to explain the relationship achievement emotions has with social media addiction and critical thinking among university students. Understanding this phenomenon can provide educators and even students with information on how social media use and critical thinking are related with emotions, which can help with decision making of the appropriateness of social media use in conjunction with academic studies in particular.

\section{CRITICAL THINKING}

Critical thinking has been defined as being aware of one's own thought process and what one is trying to do or achieve (Andolina, 2002). It involves reflecting upon what has happened and considering ways to improve (Halpern, 2013). Elder and Paul (2010) have proposed six stages of critical thinking development. In the process of going from an unreflective thinker to an accomplished thinker, a person moves from being unaware of their own thinking to being highly in tune with their thoughts and always seeking to refine and clarify them. Reflective thinking is one 
form of critical thinking and this has led to confusion among many (Elder \& Paul, 2010).

Bloom's taxonomy is another commonly used tool for explaining critical thinking (Adams, 2015). As one moves from the bottom of the taxonomy to the top more and more critical thinking is needed. Generally, the higher order thinking levels (analysis, evaluation, and creation) are considered the levels at which critical thinking take place. Common teaching strategies that encourage critical thinking include problem solving, flipping the classroom, group work and explicit instruction (Fung \& Howe, 2014; Heijltjes, van Gog, \& Paas, 2014; Kong, 2014). Lastly, a critical thinker has been found as someone who can communicate clearly, distinguish between facts and opinions, draw logical conclusion, is a convergent learner, and able to control their emotions (Belkin, 2017; Ghazivakli et al., 2014). This indicates that if social media leads to emotional issues it could be associated with the ability to think critically.

Bukist and Irons (2008) found several barriers to critical thinking for students and for teachers who are attempting to teach this skill. Barriers for students include a focus on memorising, familiarity with being told what to do, as well, as a lack of time and or knowledge to think critically. For teacher, teaching critical thinking was impeded by the difficulty in assessing it, lack of pedagogical knowledge for addressing critical thinking, and the problem that many teachers are not critical thinkers.

Students who are not native speakers of English can face additional challenges with developing critical thinking skills if they study at university in a second language. Within the context of ESL, it has been found that limited language skills can affect participation in activities that encourage critical thinking (DeWaelsche, 2015; Luk \& Lin, 2015). In addition, critical thinking has been found to predict language learning (Afshar \& Movassagh, 2017). Therefore, universities with a large population of second language users, such as international universities in Thailand, are given the additional challenge and burden of developing critically thinkers who are trying to learn to think critically in a second language when they may not know how to think critically in their mother tongue.

There are also unique characteristics to thinking critically in Asia. In China, there has been criticism of the exam-focused nature of Chinese K-12 education with the constant focus on testing impeding critical thinking skills (Hernandez, 2016). However, Lam (2016) argues against the notion that the Confucian culture of China is less rational than the West. Even though it is not conclusive either way if there is a cultural influence that is able to affect critical thinking in an Asian context, 
one study did find that graduate students in the Asian context lacked the critical thinking skills needed for advance studies (Nankervis, Prikshat, \& Cameron, 2018). As the context of this study is Thailand it is possible that cultural factors may influence perceptions of critical thinking.

\section{SOCIAL MEDIA ADDICTION}

There are several definitions of social media addiction. For example, social media addiction is the inability of a person to control their social media use (Hope, 2018). Another definition of social media addiction is the excess use of social media until it impedes other basic functions such as sleeping and eating (van Dijk, 2012). What these definitions indicate is that addiction indicates a lost of control over whatever is being used in excess.

Social media is commonly access through the cellphone and computer (Longstreet \& Brooks, 2017; Samaha \& Hawi, 2016). The pervasiveness of cellphones in particular often makes it difficult to abstain from the use of social media and people who access social media through their cellphones were more likely to become addicted to their phones (Jeong, Kim, Yum, \& Hwang, 2016; Saad, 2015). Symptoms of social media addiction include physical problems such as blurred vision, weight gain or loss, and headaches as well, as psychological problems such as agitation, anxiety, isolation, and even a loss of time and inability to complete work (PsychGuides, 2018). In general, social media addiction is usually negatively associated with life satisfaction (Longstreet \& Brooks, 2017).

Andreassen et al. (2016) found that additive technology, such as social media, can contribute to mental disorder symptoms. Social media addiction has also been linked with interfering with human relationships by influencing conversation quality, connection and closeness between people (Przybylski \& Weinstein, 2012). Even increasing face-to-face contact with other people can be neutralised if there is extensive social contact online through such a platform as social media (Yao \& Zhong, 2014). Lastly, the use of smartphones for the purpose of sociability was positively associated shyness (Bian \& Leung, 2015).

The effect of social media on academic performance is mixed (Lau, 2017; Samaha \& Hawi, 2016). Several studies found a negative association between smartphones (a platform for social media) and academic performance (Lepp et al., 2015; Samaha \& Hawi, 2016). However, Lau (2017) found that only social media use for non-academic purposes was associated with academic performance. Students are convinced that their social media use has no effect on their academic performance 
(Ozer, Karpinski, \& Kirschner, 2014). However, denial is often linked with addiction (Colder Carras et al., 2018).

\section{ACHIEVEMENT EMOTIONS}

Achievement emotions are emotions in an academic context that are tied directly to academic activities and or academic outcomes (Pekrun, Frenzel, Goetz, \& Perry, 2007). The concept of achievement emotions is derived from Control-value theory which states that achievement emotions can be explained by an individual's valence (positive vs. negative emotions), activation (activating vs. deactivating emotions), and focus (activity vs. outcome goals) (Pekrun et al., 2007).

In the educational context, teaching skills, feedback and homework have all been linked with achievement emotions (Goetz et al., 2012; Muntaner-Mas, VidalConti, Sese, \& Palou, 2017; Pekrun, Cusack, Murayama, Elliot, \& Thomas, 2014). Teaching skills in combination with positive emotions have been linked with academic control (Muntaner et al., 2017). The conditions of feedback have also been found to be related to test-related emotions (Pekrun et al., 2014). Lastly, the primary emotion students experience when completing homework or attending class is boredom (Goetz et al., 2012).

Emotions have been linked with academic performance as well. Boredom negatively predicts academic performance (Pekrun et al., 2010). However, enjoyment and pride are positive predictors of academic performance (Van der Beek, Van der Ven, Kroesbergen, \& Leseman, 2017; Pekrun, Lichtenfeld, Marsh, Murayama, \& Goetz, 2017; Villavicencio \& Bernardo, 2013). The form of assessment can also affect emotions. Assessment that contributes to moral development is viewed positively by students while negative emotions were associated with evaluating the school and or teacher's performance (Chen \& Brown, 2018).

The extant literature has not focused much on achievement emotions and social media as one common focus currently is academic performance (Lau, 2017; Lepp et al., 2015; Samaha \& Hawi, 2016). In addition, other research has examined emotions but has not included the context of academic achievement (Andreassen et al., 2016). This study will strive to bridge the gap between academic achievement and emotions as they related to social media addiction and critical thinking.

Based on this review of literature, the following questions were formulated. Figure 1 is the initial structural model. This model depicts the hypothetical 
relationships between social media addiction, critical thinking, and achievement emotions.

1. What are the perceptions of the respondents in terms of social media addiction, critical thinking, and achievement emotions?

2. Is there a difference in the perception of the respondents in terms of social media addiction, critical thinking, and achievement emotions based on sub groups determined by demographic variables?

3. Is achievement emotions linked with critical thinking and social media addiction?

4. Is critical thinking linked with social media addiction?

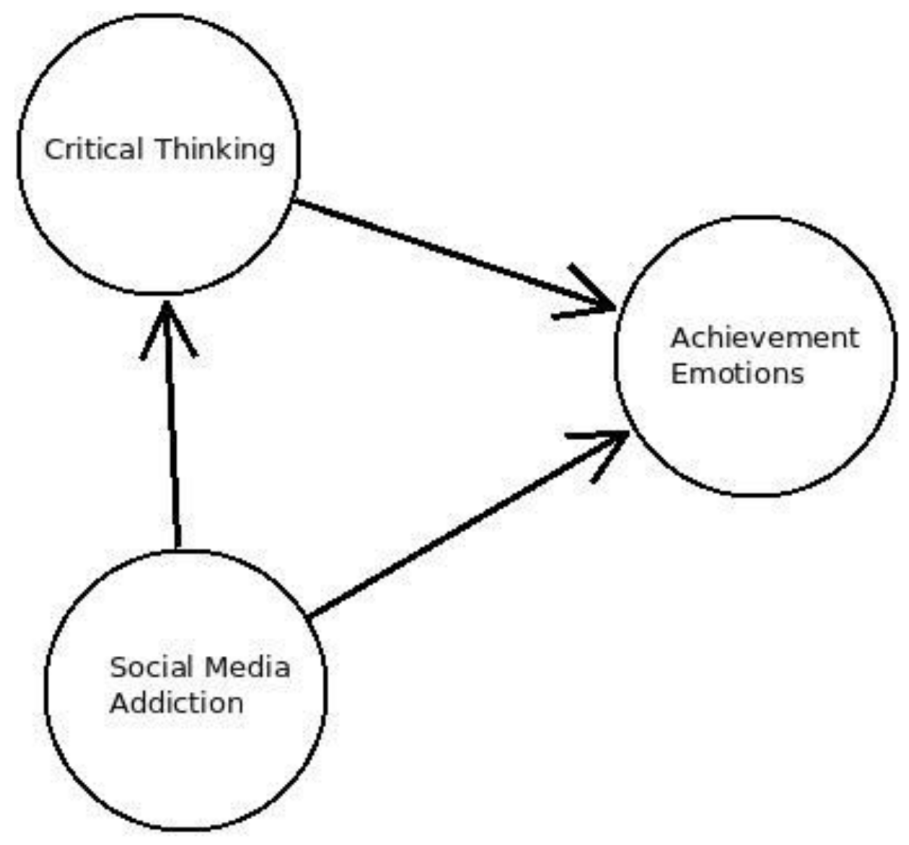

Figure 1. Initial structural model

\section{METHODOLOGY}

The population of this study was university students in Thailand. The setting of this study was a university located in Thailand. The sample of 230 respondents was derived using stratified sampling based on gender from one Thai university. In the sample, $61 \%$ were female and 39\% were male. The discrepancy in the number of men and women in the sample is consistent with the population of the study. For 
class level, $35 \%$ were freshman, $19 \%$ were sophomores, $25 \%$ were juniors, and $21 \%$ were seniors. In terms of major, business made up of $23 \%$, education $(18 \%)$, English (47\%), religion (6\%) and science (6\%). The setting was selected due to the high concentration of university students who generally use social media and are in an environment that is trying to develop critical thinking skills with an emphasis on achievement.

\section{RESEARCH DESIGN AND INSTRUMENTS}

A cross-sectional survey was used in this study. The data was collected by the researcher at the setting through distributing the survey to participants at the university. Data collection took approximately three weeks to complete. The instrument used in this study consisted of two sections. Section 1 addressed demographic variables such as class level, gender, and major. Section 2 of the instrument consisted of 53 Likert-type statements that measure each respondents' perception of one of the three observed variables of this study (critical thinking, social media disorder, and achievement emotions). The Likert-scale used for the observed variables was a 5-point scale: 1 (strongly disagree), 2 (disagree), 3 (neutral), 4 (agree), 5 (strongly agree).

The critical thinking scale was developed by Mincemoyer, Perkins and Munyua (2001). This scale measures attitudes and behaviours toward critical thinking as perceived by the respondents. Sample items include "I am able to give reasons for my opinions." and "I compare ideas when thinking about a topic." The 20-item scale has a Cronbach alpha of 0.90 .

The social media disorder scale was developed by van den Eijnden, Lemmens and Valkenburg (2016). This scale measures attitudes toward symptoms of social media addiction as perceived by the respondents. Sample items include "I often feel bad when I cannot use social media." and "I often used social media to escape from negative feelings." The 9-item scale has a Cronbach's alpha of 0.77.

The achievement emotions scale was developed by Pekrun, Goetz, Titz and Perry (2002). This scale measures attitudes and behaviors toward emotions experience in an educational context as perceived by the respondents. Sample items include "I get bored in class." and "I get tense and nervous while studying." The 24-item scale has a Cronbach's alpha of 0.82 . 


\section{Data Analysis}

Descriptive statistics were calculated, as well as $t$-test and ANOVA for the purpose of comparisons based on subgroups derived from the demographic variables. A model was developed using path analysis, which is a form of structural equation modelling (SEM).

\section{RESULTS AND DISCUSSION}

The descriptive results indicated for social media addiction that the students disagree with the statements that indicate symptoms of social media addiction $(M=2.48, S D=0.58)$. Students stated in Item 2 that they disagree that they "often feel bad when [they] cannot use social media" $(M=2.47, S D=0.93)$. However, students were neutral in their response to Item 4 that they "try to spend less time on social media but fail" $(M=3.10, S D=1.02)$.

For critical thinking students moderately agreed that they use critical thinking skills $(M=3.61, S D=0.48)$. For example, in Item 40 , students agreed that "it is important for [them] to get information to support [their] conclusion" $(M=3.85$, $S D=0.71$ ). However, students were more neutral in their response to Item 52 that indicated they are able to "develop a checklist to help [them] think about an issue" $(M=3.24, S D=0.86)$.

In regards to achievement emotions, students were neutral towards the statements $(M=3.40, S D=0.39)$. Students indicate in Item 13 that they are "[not] angry after attending class" $(M=3.94, S D=0.98)$. In addition, students indicated in item 29 that they disagree that they "feel very relieved after an exam" $(M=2.28$, $S D=0.99)$.

For comparisons by groups, no difference was found by gender or class for critical thinking, social media addiction, or achievement emotions. There was a difference by major for social media addiction $[F(4,212)=4.06, p<0.01]$. Post hoc comparisons using the Tukey HSD test indicated that the mean score for the English majors $(M=2.61, S D=0.58)$ was significantly different from Business majors $(M=2.25, S D=0.55)$.

The results of the structural model indicated a good fit $\chi^{2}(0)=0, p<.05$, TuckerLewis Index $(\mathrm{TLI})=1.0$, incremental fit index $(\mathrm{IFI})=1.0$, comparative fit index $(\mathrm{CFI})=1.0$, root mean square error of approximation $(\mathrm{RMSEA})=0.00,95 \%$ confidence interval (CI) $[0.00,0.00]$. 
The structural model assessed the correlations between the observed variables. It was found that critical thinking is directly linked positively with achievement emotions $(b=0.22, t(229)=4.58, p<0.01)$. Social media addiction was also found to be directly associated negatively with achievement emotions $(b=-0.19, t(229)$ $=-7.20, p<0.01)$. Together, critical thinking and social media addiction explain $27 \%$ of the variance of achievement emotions. In addition, social media addiction is directly linked negatively with critical thinking $(b=-0.11, t(229)=-3.09$, $p<0.01)$ and explains $4 \%$ of the variance of critical thinking. Table 1 shows the means, standard deviations and correlations among the observed variables.

Table 1. Means, standard deviations, and correlations with confidence intervals

\begin{tabular}{llcccc}
\hline & Variable & $\mathrm{M}$ & $\mathrm{SD}$ & 1 & 2 \\
\hline 1 & Social media & 2.48 & 0.59 & & \\
2 & Achievement motions & 3.39 & 0.39 & $-.46^{* *}$ & \\
& & & & {$[-.55,-.35]$} & \\
3 & Critical thinking & 3.61 & 0.47 & $-.20^{* *}$ & $.37 * *$ \\
& & & & {$[-.32,-.07]$} & {$[.25, .47]$} \\
\hline
\end{tabular}

Notes: * indicates $p<.05 ; * *$ indicates $p<.01 . \mathrm{M}$ and SD are used to represent mean and standard deviation, respectively. Values in square brackets indicate the $95 \%$ confidence interval for each correlation.

There were several significant findings in this study. First, social media addiction is negatively linked to achievement emotions and critical thinking. Based on the responses indicate on the survey this means that if a person agrees that they struggle to spend less time with social media, use social media to escape negative feelings, and or neglect other activities due to social media use these same individuals are more inclined to disagree that they enjoy being in class, are confident when they go to class, as well, as agree that they are bored with class, and annoyed after an exam. Other studies have examined social media addiction and its role in academic performance (Lau, 2017; Samaha \& Hawi, 2016). In addition, other studies have also found and agree with this study that addictions like social media can affect emotional well-being (Andreassen et al., 2016; Thomas, 2016). However, this paper provides evidence of a strong negative link between social media addiction and emotions associated with achievement in an academic context.

Second, social media was also negatively linked with critical thinking. What this means is that as student agreed more with statements that identified symptoms of social media addiction they were less likely to agree that they identify options when facing a problem, are able to give reasons for their opinion, and or put their ideas in order by importance. Few studies have examined critical thinking, as it is associated with social media addiction as the focus of many studies has been upon 
academic performance (Lepp et al., 2015; Samaha \& Hawi, 2016). This has been the focus despite the fact that critical thinking is often a prerequisite for academic performance (Andolina, 2002; Bukist \& Irons, 2008). This study has found a weak negative association between social media addiction and critical thinking. Therefore, this study has uncovered an association that has not been examined closely in prior research.

A third finding was a weak positive relationship between critical thinking and achievement emotions. This indicates that students who agree with statements that indicate critical thinking skills also often agree with statements that show positive emotions towards achievement. There are several studies that have identified how emotions affect thinking and this study validates prior work (Chien Chih, Mei Yao, Chung Ju, Lu, \& HsinYu, 2015; Muis, Psaradellis, Lajoie, Di Leo, \& Chevrier, 2015). In addition, there is even evidence that critical thinkers are able to have control of their emotions (Belkin, 2017; Ghazivakli et al., 2014). However, this study has provided evidence that critical thinkers are sometimes individuals with positive emotions in relation to achievement in an academic context.

A fourth lesser finding is the lack of a difference by gender for critical thinking, social media addiction, and achievement emotions. There are several older studies that support that there is no difference by gender in terms of critical thinking (Kuhn, 1992; Magolda, 1992). The lack of differences for social media addiction and achievement emotions may be cultural. Thailand is one of the top ten social media use countries in the world indicating that heavy use for the typical user is common (Leesa-Nguansak, 2018). For emotions, culturally, Thailand tends to exercise restraint in expressing and communicating emotions (Komin, 1991). Therefore, the responses on the survey may have been suppressed by this.

\section{CONCLUSION AND RECOMMENDATIONS}

One recommendation for consideration is that caution should be taken in regards to the use of social media among students. This is based on the strong negative association of social media addiction with critical thinking and achievement emotions. Given that this study explained half the variance of achievement emotions with social media addiction and critical thinking it appears that if someone is struggling with social media, they may also be struggling with having positive emotions about achievement.

A second recommendation is that institutions should have mechanisms to avoid heavy integration of social media into the learning experiences due to the negative 
relationship it has with critical thinking and achievement emotions. Often it is possible to integrate social media into the learning management system of the campus that is used for online learning (Guess, 2008). However, this should be done with restraint so that students are not overly exposed to a tool that can at times have a detrimental effect. With this in mind, it is necessary to employ cooperation rather than conflict when considering the use of social media in education in order to provide an experience in which students can learn through this medium when necessary.

A third recommendation which relates to further studies is that it would be beneficial to develop experimental studies that manipulate social media use to determine its influence on academic performance, emotions, and or critical thinking. Establishing a cause and effect relationship would help to make a stronger conclusion for or against the use of social media among students. Lastly, this study was correlational and cannot determine conclusively cause and effect.

This study's purpose was to explain achievement emotions through its relationship with social media addiction and critical thinking. Critical thinking played a minor role in achievement emotions. However, social media addiction has a strong negative association with achievement emotions and a weak negative association with critical thinking. This indicates that at a minimum caution should be exercise with the use of social media among students.

\section{REFERENCES}

Adams, N. (2015). Bloom's taxonomy of cognitive learning objectives. Journal of the Medical Library Association, 103(3), 152-153. https://doi.org/10.3163/15365050.103.3.010

Afshar, H., \& Movassagh, H. (2017). On the relationship among critical thinking, language learning strategy use and university achievement of Iranian English as a foreign language majors. The Language Learning Journal, 45(3), 382-398. https://doi.or $\mathrm{g} / 10.1080 / 09571736.2014 .914238$

Andolina, M. (2002). Practical guide to critical thinking. Albany, NY: Delmar.

Andreassen, S., Billieux, J., Griffiths, D., Kuss, J., Demetrovics, Z., Mazzoni, E., \& Pallesen, S. (2016). The relationship between addictive use of social media and video games and symptoms of psychiatric disorders: A large-scale crosssectional study. Psychology of Addictive Behaviors, 30(2), 252-262. https://doi .org/10.1037/adb0000160

Belkin, D. (2017). Exclusive test data: Many colleges fail to improve critical-thinking skills. Retrieved from https://www.wsj.com/articles/exclusive-test-data-manycolleges-fail-to-improve-critical-thinking-skills-1496686662 
Bian, M., \& Leung, L. (2015). Linking loneliness, shyness, smartphone addiction symptoms, and patterns of smartphone use to social capital. Social Science Computer Review, 33(1), 61-79. https://doi.org/10.1177/0894439314528779

Bukist, W., \& Irons, J. (2008). Simple strategies for teaching your students to think critically. In D. Dunn, J. Halonen, \& R. Smith (Eds.), Teaching critical thinking in psychology: A handbook of best practices (Vol. 1, pp. 49-57). John Wiley \& Sons. https://doi.org/10.1002/9781444305173.ch5

Chen, J., \& Brown, G. (2018). Chinese secondary school students' conceptions of assessment and achievement emotions: Endorsed purposes lead to positive and negative feelings. Asia Pacific Journal of Education, 38(1), 1-19. https://doi.org/ 10.1080/02188791.2018.1423951

Chien Chih, C., Mei Yao, H., Chung Ju, H., Lu, F. J. H., \& HsinYu, T. (2015). The mediating role of critical thinking on motivation and peer interaction for motor skill performance. International Journal of Sport Psychology, 46(5), 391-408. Retrieved from https://www.cabdirect.org/cabdirect/abstract/20153378240

Colder Carras, M., Porter, A. M., Van Rooij, A. J., King, D., Lange, A., Carras, M., \& Labrique, A. (2018). Gamers' insights into the phenomenology of normal gaming and game "addiction": A mixed methods study. Computers in Human Behavior, 79, 238-246. https://doi.org/10.1016/j.chb.2017.10.029

DeWaelsche, S. (2015). Critical thinking, questioning and student engagement in Korean university English courses. Linguistics and Education, 32, 131-147. https://doi .org/10.1016/j.linged.2015.10.003

Elder, L., \& Paul, R. (2010). Critical thinking development: A stage theory. Retrieved from http:/www.criticalthinking.org/pages/critical-thinking-development-astage-theory $/ 483$

Fernquest, J. (2017). Educational inequality in Thailand: The challenge. Bangkok Post, 31 May. Retrieved from https:/www.bangkokpost.com/learning/advanced/1259777/ educational-inequality-in-thailand-the-challenge

Freedberg, L. (2016). Teachers say critical thinking key to college and career readiness. Retrieved 28 February 2018, from https://edsource.org/2015/teachers-saycritical-thinking-most-important-indicator-of-student-success $/ 87810$

Fung, D., \& Howe, C. (2014). Group work and the learning of critical thinking in the Hong Kong secondary liberal studies curriculum. Cambridge Journal of Education, 44(2), 245-270. https://doi.org/10.1080/0305764X.2014.897685

Ghazivakli, Z., Nia, R., Panahi, F., Karimi, M., Gholosorkhi, H., \& Ahmadi, Z. (2014). The role of critical thinking skills and learning styles of university students in their academic performance. Journal of Advances in Medical Education and Professionalism, 2(3), 95-102.

Go-Global. (2014, December). Social media addiction: Statistics and trends. Retrieved from https://www.go-globe.com/blog/social-media-addiction/

Goetz, T., Nett, U. E., Martiny, S. E., Hall, N. C., Pekrun, R., Dettmer, S., \& Trautwein, U. (2012). Students' emotions during homework: Structures, self-concept antecedents, and achievement outcomes. Learning and Individual Differences, 22(2), 225-234. https://doi.org/10.1016/j.lindif.2011.04.006 
Guess, A. (2008). Facebook, meet blackboard. Retrieved 9 May 2018, from https://www. insidehighered.com/news/2008/05/14/sync

Halpern, D. (2013). Thought and knowledge: An introduction to critical thinking. New York: Psychology Press. https://doi.org/10.4324/9781315885278

Heijltjes, A., van Gog, T., \& Paas, F. (2014). Improving students' critical thinking: Empirical support for explicit instructions combined with practice. Applied Cognitive Psychology, 28(4), 518-530. https://doi.org/10.1002/acp.3025

Hernandez, J. (2016, July). Study finds Chinese students excel in critical thinking. Until College. New York Times. Retrieved from https://www.nytimes.com/2016/07/31/ world/asia/china-college-education-quality.html

Hope, J. (2018). Could educational technology replace traditional schools in the future? In M. Khosrow-Pour (Ed.), Encyclopedia of information science and technology (4th ed., pp. 2421-2430). Hershey, PA: IGI Global. https://doi.org/10.4018/978$1-5225-2255-3 . \operatorname{ch} 211$

Jeong, S., Kim, H., Yum, J., \& Hwang, Y. (2016). What type of content are smartphone users addicted to? SNS vs. games. Computers in Human Behavior, 54, 10-17. https://doi.org/10.1016/j.chb.2015.07.035

Komin, S. (1991). Psychology of the Thai people: Values and behavioral patterns. National Institute of Development and Administration.

Kong, S. (2014). Developing information literacy and critical thinking skills through domain knowledge learning in digital classrooms: An experience of practicing flipped classroom strategy. Computers \& Education, 78, 160-173. https://doi. org/10.1016/j.compedu.2014.05.009

Kuhn, D. (1992). Thinking as Argument. Harvard Educational Review, 62(2), 155-179. https://doi.org/10.17763/haer.62.2.9r424r0113t67011

Lam, C. (2016). Does Confucianism Hinder critical thinking in education? Sociological and Philosophical Perspectives on Education in the Asia-Pacific Region, 29, 179-192. https://doi.org/10.1007/978-981-287-940-0_12

Lane, D., \& Oswald, F. (2016). Do 45\% of college students lack critical thinking skills? Revisiting a central conclusion of Academically Adrift. Educational Measurement: Issues and Practice, 35(3), 23-25. https://doi.org/10.1111/emip.12120

Lau, W. (2017). Effects of social media usage and social media multitasking on the academic performance of university students. Computers in Human Behavior, 68 , 286-291. https://doi.org/10.1016/j.chb.2016.11.043

Leesa-Nguansak, S. (2018). Thailand makes top 10 in social media use. Retrieved 1 March 2018, from https://www.bangkokpost.com/business/news/1420086/thailandmakes-top-10-in-social-media-use

Lepp, A., Barkley, J., \& Karpinkski, A. (2015). The relationship between cell phone use and academic performance in a sample of U.S. college students. SAGE Open, 5(1), 1-9. https://doi.org/10.1177/2158244015573169

Longstreet, P., \& Brooks, S. (2017). Life satisfaction: A key to managing internet \& social media addiction. Technology in Society, 50, 73-77. https://doi.org/10.1016/j .techsoc.2017.05.003 
Luk, J., \& Lin, A. (2015). Voices without words: Doing critical literate talk in English as a second language. TESOL Quarterly, 49(1), 67-91. https://doi.org/10.1002/ tesq. 161

Magolda, M. B. B. (1992). Knowing and reasoning in college: Gender-related patterns in students' intellectual development. Wiley.

Mincemoyer, C., Perkins, D., \& Munyua, C. (2001). Critical thinking in everyday life | CYFAR. Retrieved 19 February 2018, from https://cyfar.org/critical-thinkingeveryday-life

Muis, K. R., Psaradellis, C., Lajoie, S. P., Di Leo, I., \& Chevrier, M. (2015). The role of epistemic emotions in mathematics problem solving. Contemporary Educational Psychology, 42, 172-185. https://doi.org/10.1016/j.cedpsych.2015.06.003

Muntaner-Mas, A., Vidal-Conti, J., Sese, A., \& Palou, P. (2017). Teaching skills, students' emotions, perceived control and academic achievement in university students: A SEM approach. Teaching and Teacher Education, 67, 1-8. https://doi.org /10.1016/j.tate.2017.05.013

Nankervis, A., Prikshat, V., \& Cameron, R. (2018). Graduate work-readiness in Asia Pacific economies: A review of the literature. In R. Cameron, S. Dhakal, \& J. Burgess (Eds.), Transitions from education to work workforce ready challenges in the Asia Pacific. Taylor-Francis. https://doi.org/10.4324/9781315533971-2

Ozer, I., Karpinski, A., \& Kirschner, P. (2014). A cross-cultural qualitative examination of social-networking sites and academic performance. Procedia - Social and Behavioral Sciences, 112,873-881.https://doi.org/10.1016/j.sbspro.2014.01.1244

Pekrun, R., Cusack, A., Murayama, K., Elliot, A., \& Thomas, K. (2014). The power of anticipated feedback: Effects on students' achievement goals and achievement emotions. Learning and Instruction, 29, 115-124. https://doi.org/10.1016/j .learninstruc.2013.09.002

Pekrun, R., Frenzel, A. C., Goetz, T., \& Perry, R. P. (2007). The control-value theory of achievement emotions: An integrative approach to emotions in education. In P. A. Schutz, \& and R. Pekrun (Eds.), Emotion in education (pp. 13-36). Burlington: Academic Press. https://doi.org/10.1016/B978-012372545-5/50003-4

Pekrun, R., Goetz, T., Daniels, L., Stupinsky, R., \& Perry, R. (2010). Boredom in achievement settings: Exploring control-value antecedents and performance outcomes of a neglected emotion. Journal of Educational Psychology, 102(3), 531-549. https://doi.org/10.1037/a0019243

Pekrun, R., Goetz, T., Titz, W., \& Perry, R. (2002). Academic emotions in students' selfregulated learning and achievement: A program of qualitative and quantitative research. Educational Psychologist, 2, 91-105. https://doi.org/10.1207/ S15326985EP3702 4

Pekrun, R., Hall, N. C., Goetz, T., \& Perry, R. P. (2014). Boredom and academic achievement: Testing a model of reciprocal causation. Journal of Educational Psychology, 106(3), 696-710. https://doi.org/10.1037/a0036006

Przybylski, A., \& Weinstein, N. (2012). Can you connect with me now? How the presence of mobile communication technology influences face-to-face conversation quality. Journal of Social and Personal Relationships, 30(3), 237-246. https:// doi.org/10.1177/0265407512453827 
PsychGuides. (2018). Computer/internet addiction: Symptoms, causes and effects. Retrieved from https://www.psychguides.com/guides/computerinternetaddiction-symptoms-causes-and-effects/

Ranellucci, J., Geotz, T., \& Hall, N. (2015). Achievement goals, emotions, learning, and performance: A process model. Motivation Science, 1, 98-120. https://doi .org/10.1037/mot0000014

Saad, L. (2015). Nearly half of smartphone users can't imagine life without it. Retrieved from http://www.gallup.com/poll/184085/nearly-half-smartphone-users-imaginelife-without.aspx?utm_source=Economy\&utm_medium=newsfeed\&utm campaign $=$ tiles

Samaha, M., \& Hawi, N. (2016). Relationships among smartphone addiction, stress, academic performance, and satisfaction with life. Computers in Human Behavior, 57, 321-325. https://doi.org/10.1016/j.chb.2015.12.045

Smith, A., \& Anderson, M. (2018, 1 March). Social media use in 2018. Retrieved 9 May 2018, from http://www.pewinternet.org/2018/03/01/social-media-use-in-2018/

Statista. (2018). Number of worldwide social network users 2010-2021. Retrieved 9 May 2018, from https://www.statista.com/statistics/278414/number-of-worldwidesocial-network-users/

Thomas, D. (2016). Cellphone addiction and academic stress among university students in Thailand. International Forum, 19(2), 80-96. Retrieved from http://journals.aiias. edu/iforum/article/view/187/191

van den Eijnden, R. J. J. M., Lemmens, J. S., \& Valkenburg, P. M. (2016). The social media disorder scale. Computers in Human Behavior, 61, 478-487. https://doi .org/10.1016/j.chb.2016.03.038

Van der Beek, J. P. J., Van der Ven, S. H. G., Kroesbergen, E. H., Paul P M Leseman, P. P. M. (2017). Self-concept mediates the relation between achievement and emotions in mathematics. The British Journal of Educational Psychology, 87(3), 478-495. https://doi.org/10.1111/bjep.12160

van Dijk, J. (2012). The network society (3rd ed.). Thousand Oaks, CA: Sage.

Villavicencio, F. T., \& Bernardo, A. B. I. (2013). Positive academic emotions moderate the relationship between self-regulation and academic achievement. The British Journal of Educational Psychology, 83(Pt 2), 329-340. https://doi.org/10.1111/ j.2044-8279.2012.02064.x

Yao, Z., \& Zhong, Z. (2014). Loneliness, social contacts and Internet addiction: A crosslagged panel study. Computers in Human Behavior, 30, 164-170. https://doi .org/10.1016/j.chb.2013.08.007 